\title{
Polymorphisms in P53 and VEGFA genes in different subtypes of periorbital hyperpigmentation \\ E.M.K.Sanad ${ }^{1}$, S.H.Ahmed ${ }^{1}$, N.F.Alhusseini ${ }^{2}$ and H.W.S.Alsadik ${ }^{1}$ \\ ${ }^{1}$ Dermatology, Venereology and Andrology, Dept., Faculty of Medicine, Benha Univ., Benha, Egypt \\ ${ }^{2}$ Medical Biochemistry, Dept., Faculty of Medicine, Benha Univ., Benha, Egypt \\ E-mail:halla226@yahoo.com
}

\begin{abstract}
A black eye circle or periorbital hyperpigmentation affects men and women alike. The periocular area is affected by a poorly defined lesion that appears as round or semicircular brown or dark brown pigmented macules. VEGFA (rs833061) and P53 (rs1042522) polymorphisms were detected in various periorbital hyperpigmentation types. Methods: Thirty patients with periorbital hyperpigmentation were included in this prospective case-control research, along with twenty seemingly healthy control individuals of the same age and gender. The distribution of p53 and VEGFA genotypes in patients and controls did not vary significantly. Cases with POH were more likely to have p53 genotypes Pro/Pro and Arg/Pro+Pro/Pro than controls. A greater frequency of the VEGFA TC, CC, TC+CC genotypes, and the $\mathrm{C}$ allele were found in patients compared to the control group with POH risk. The VEGFA TC genotype was associated with the pigmented subtype. Periorbital hyperpigmentation was more likely to occur in those with the p53-pro/pro and arg/pro+pro/pro genotypes, the pro allele, VEGFA-TC, TC+CC, and C allele genotypes. There was a strong association between the VEGFA TC genotype and the pigment subtype. Otherwise. There was no relationship between VEGFA rs833061 and any of the VEGFA variants (p53 rs1042522 or p53 rs1042522). For orbital hyperpigmentation susceptibility, P53 and VEGFA genotypes have been proposed as risk factors.
\end{abstract}

Keywords: Polymorphisms, P53, VEGFA, periorbital, hyperpigmentation.

\section{Introduction}

Hyperpigmentation of the periorbital region, commonly known as dark eye circles, affects men and women alike. Few studies have examined the aetiology of periorbital hyperpigmentation and its clinical manifestations. Asthma, allergic rhinitis, atopic dermatitis, sleeplessness, systemic disorders, dietary inadequacies, and psychological difficulties have all been linked to it. Pigmented (brown colour) and vascular (blue/pink/purple hue) hyperpigmentation subtypes have been identified, as well as mixed subtypes [1].

Because it contains less collagen, elastin, and glycosaminoglycans, the skin above the lower eyelid is thinner and looser than other skin areas. However, the precise mechanism is unknown, and there are no effective therapies [2].

A periorbital hyperpigmentation may have both epidermal and dermal features [3].

It regulates cell cycle, DNA transcription and repair, apoptosis, and genome stability, and serves as a tumour suppressor gene. It has 11 exons and is found on the short arm of chromosome 17 [4].

As a result of physiologic stressors like as sun tanning, inflammation, and ageing, the expression of the gene p53 may be elevated in the area of the periorbital hyperpigmentation.

We thus hypothesise that p53 gene variation and periorbital hyperpigmentation may be linked [5].

Vegfa is one of the most important mediators of angiogenesis and plays a key role in cancer development by stimulating tumour growth. Cancer susceptibility is linked with polymorphisms in VEGFA, such as glioma, hepatocellular carcinoma, ovarian cancer, bladder cancer, and breast cancer, among others. On chromosome 6, the human VEGFA gene is structured into 8 exons [6].
We believe that genetic variation in VEGFA may also contribute to periorbital hyperpigmentation, because the presence of large arteries beneath the skin is frequent in certain forms of periorbital hyperpigmentation.

VEGFA and P53 single nucleotide polymorphisms (SNPs) will be detected in various subtypes of periorbital hyperpigmentation in the current research.

\section{Patients and methods}

This prospective case-control study included 30 patients suffering from periorbital hyperpigmentation, in addition to 20 apparently healthy control subjects of matched age and sex. All patients were selected from the outpatient clinic of Dermatology, Venereology and Andrology Department of Benha University Hospitals in the period between March and October 2020.

The study was approved by the local ethics committee on research involving human subjects of Benha Faculty of Medicine. A written informed consent was obtained from all participants before samples collection.

\subsection{Exclusion Criteria}

Patients with periorbital hyperpigmentation due to

1- Naevo-melanoytic naevi

2- Naevus of Ota, Hori naevus or ephelides

3-Shadow subtype periorbital hyperpigmentation (due to prominent orbital rim)

4-Localized postinflammatory hyperpigmentation (due to a recognizable insult or injury), tattoo, bruising and cosmetic residual.

All patients were subjected to Full history taking, and clinical examination to evaluate: clinical subtypes and pigmentation pattern. 


\subsection{Genetic analyses}

$2 \mathrm{ml}$ of peripheral venous blood samples was collected under complete aseptic conditions in tubes with EDTA anticoagulant from all participants, and DNA was isolated from the samples. Genotyping for the polymorphisms was performed using Restriction Fragment Length Polymorphism (RFLP-PCR) technique.

\subsection{Statistical analysis}

The collected data was revised, coded, tabulated and introduced to a PC using Statistical package for Social Science (IBM Corp. Released 2017. IBM SPSS Statistics for Windows, Version 25.0. Armonk, NY: IBM Corp.). Data were presented and suitable analysis was done according to the type of data obtained for each parameter. Descriptive statistics: Mean, Standard deviation ( \pm SD) for numerical data. Frequency and percentage of non-numerical data. Shapiro test was done to test the normality of data distribution. Significant data was considered to be nonparametric. Analytical statistics: Student $\mathrm{T}$ Test was used to assess the statistical significance of the difference between two study group means. For the comparison of the three groups' means, one way analysis of variance (ANOVA) was used. Chi-Square test was used to examine the relationship between two qualitative variables.

\section{Results}

The current study included 30 periorbital hyperpigmentation cases, their mean age was 33.4 years $(\mathrm{SD}=10.9)$ years. They comprised 3 males $(10 \%)$ and 27 females (90\%). Control group was selected to be matched in age and gender $(p>0.05)$. Their mean age was 33.6 years, they were 4 males $(20 \%)$ and 16 females $(80 \%)$ table (1).

Numerical data are expressed as mean and SD, compared by t test; categorical data are expressed as number and percentage; compared by chi square $\left(\mathrm{X}^{2}\right)$ test.

The studied rs1042522 SNP comprised of G and $\mathrm{C}$ alleles. It is located on short arm of chromosome 17 within p53 gene. Chang of CCC codon into CGC results in change of amino acid from proline to arginine. The studied rs $833061 \mathrm{SNP}$, comprised of T and $\mathrm{C}$ alleles. It is located on short arm of chromosome 6 within VEGFA gene. The subjects were selected randomly from population in Menofeya Governorate in Egypt. They were unrelated. Hardy Weinberg equation revealed that p53 as well as VEGFA genotypes in both cases and control subjects were in $\mathrm{HW}$ equilibrium table (2).

No significant differences were found regarding age, gender, family history and BMI according to p53 genotypes in all studied cases ( $p>0.05$ for each) table (3).

Table (1) Comparison of age and gender distribution between studied groups.

\begin{tabular}{|c|c|c|c|c|c|}
\hline & & $\begin{array}{c}\text { Control } \\
\mathbf{N}=\mathbf{2 0}\end{array}$ & $\begin{array}{l}\text { Peri orbital hyperpigmentation } \\
\qquad \mathbf{N}=\mathbf{3 0}\end{array}$ & test & $\mathbf{P}$ \\
\hline \multirow[t]{2}{*}{ Age (years) } & Mean & 33.6 & 33.4 & $\mathrm{~T}=0.081$ & 0.936 \\
\hline & $\pm \mathrm{SD}$ & \pm 8.3 & \pm 10.9 & & \\
\hline \multirow[t]{2}{*}{ Male } & $\mathbf{N}$ & 4 & 3 & & \\
\hline & $\%$ & $20 \%$ & $10 \%$ & $X^{2}=0.997$ & 0.416 \\
\hline \multirow[t]{2}{*}{ Female } & $\mathbf{N}$ & 16 & 27 & & \\
\hline & $\%$ & $80 \%$ & $90 \%$ & & \\
\hline
\end{tabular}

Table (2) Assessment of Hardy Weinberg equilibrium for p53 and VEGFA genotypes.

\begin{tabular}{|c|c|c|c|c|c|}
\hline & & \multicolumn{2}{|c|}{$\begin{array}{c}\text { Control } \\
\mathrm{N}=20\end{array}$} & \multicolumn{2}{|c|}{$\begin{array}{l}\text { periorbital hyperpigmentation } \\
\qquad \mathbf{N}=30\end{array}$} \\
\hline & & Observed & Expected & Observed & Expected \\
\hline \multirow[t]{5}{*}{ p53 } & Arg/Arg & 11 & 9.1 & 6 & 3.7 \\
\hline & Arg/Pro & 5 & 8.8 & 9 & 13.7 \\
\hline & Pro/Pro & 4 & 2.1 & 15 & 12.7 \\
\hline & & \multicolumn{2}{|c|}{$X^{2}=3.757$} & \multicolumn{2}{|c|}{$X^{2}=3.499$} \\
\hline & $\mathbf{P}$ & \multicolumn{2}{|c|}{0.054} & \multicolumn{2}{|c|}{0.062} \\
\hline \multirow[t]{5}{*}{ VEGFA } & TT & 10 & 10.5 & 4 & 5.2 \\
\hline & $\mathbf{T C}$ & 9 & 8.0 & 17 & 14.6 \\
\hline & $\mathrm{CC}$ & 1 & 1.5 & 9 & 10.2 \\
\hline & & \multicolumn{2}{|c|}{$X^{2}=0.315$} & \multicolumn{2}{|c|}{$X^{2}=0.813$} \\
\hline & $\mathbf{P}$ & \multicolumn{2}{|c|}{0.565} & \multicolumn{2}{|c|}{0.364} \\
\hline
\end{tabular}

HW, Hardy Weinberg. 
P1, comparison between Arg/Arg, Arg/Pro, Pro/Pro; p2, comparison between Arg/Arg, Arg/Pro+Pro/Pro. Numerical data are expressed as mean and SD, compared by t test for two groups, ANOVA for more than two groups; categorical data are expressed as number and percentage; compared by Chi square or Fisher exact tests.

No significant differences were found regarding hyperpigmentation subtypes according to p53 genotypes in all studied patients ( $>0.05$ for each) table (4).

P1, comparison between Arg/Arg, Arg/Pro, Pro/Pro; p2, comparison between Arg/Arg, Arg/Pro+Pro/Pro. categorical data are expressed as number and percentage; compared by Chi square or Fisher exact tests.

No significant differences were found regarding hyperpigmentation patterns according to p53 genotypes in all studied patients $(\mathrm{p}>0.05)$. table 5

P1, comparison between Arg/Arg, Arg/Pro, Pro/Pro; p2, comparison between Arg/Arg, Arg/Pro+Pro/Pro. categorical data are expressed as number and percentage; compared by Chi square or Fisher exact tests.

No significant differences were found regarding age, gender, family history and BMI according to VEGFA genotypes in all studied cases $(p>0.05$ for each) table (6).

Table (3) Comparison of demographic, family history and BMI according to p53 genotypes in all studied patients.

\begin{tabular}{|c|c|c|c|c|c|c|c|c|c|}
\hline & & $\begin{array}{l}\text { Arg/Arg } \\
\mathrm{N}=6\end{array}$ & $\begin{array}{l}\text { Arg/Pro } \\
\mathrm{N}=9\end{array}$ & $\begin{array}{l}\text { Pro/Pro } \\
\mathrm{N}=15\end{array}$ & $\begin{array}{l}\text { Arg/Pro+ } \\
\text { Pro/Pro } \\
\text { N=24 }\end{array}$ & Test1 & $\mathbf{P}^{1}$ & Test 2 & $\mathbf{P}^{2}$ \\
\hline Age (years) & $\begin{array}{l}\text { mean } \\
\pm \mathrm{SD}\end{array}$ & $\begin{array}{l}34.3 \\
\pm 9.5\end{array}$ & $\begin{array}{l}33.9 \\
\pm 10.1\end{array}$ & $\begin{array}{l}32.7 \\
\pm 10.1\end{array}$ & $\begin{array}{l}33.1 \\
\pm 10.5\end{array}$ & $\mathrm{~F}=0.060$ & 0.942 & $\mathrm{~T}=0.238$ & 0.814 \\
\hline Male & $\begin{array}{l}\mathbf{N} \\
\%\end{array}$ & $\begin{array}{l}0 \\
0 \%\end{array}$ & $\begin{array}{l}1 \\
11.1 \%\end{array}$ & $\begin{array}{l}2 \\
13.3 \%\end{array}$ & $\begin{array}{l}3 \\
12.5 \%\end{array}$ & $\begin{array}{l}X 2=0.8 \\
64\end{array}$ & 0.649 & $X 2=0833$ & \\
\hline Female & $\begin{array}{l}\mathrm{N} \\
\%\end{array}$ & $\begin{array}{l}6 \\
100 \%\end{array}$ & $\begin{array}{l}8 \\
88.9 \%\end{array}$ & $\begin{array}{l}13 \\
86.7 \%\end{array}$ & $\begin{array}{l}21 \\
87.5 \%\end{array}$ & & & & 0.361 \\
\hline $\begin{array}{l}\text { Positive family } \\
\text { history }\end{array}$ & $\begin{array}{l}\mathbf{N} \\
\%\end{array}$ & $\begin{array}{l}2 \\
33.3 \%\end{array}$ & $\begin{array}{l}5 \\
55.6 \%\end{array}$ & $\begin{array}{l}10 \\
66.7 \%\end{array}$ & $\begin{array}{l}15 \\
62.5 \%\end{array}$ & $\begin{array}{l}X 2=1.9 \\
46\end{array}$ & 0.436 & $\begin{array}{l}X 2=1.66 \\
3\end{array}$ & 0.360 \\
\hline BMI (Kg/m2) & $\begin{array}{l}\text { mean } \\
\pm \text { SD }\end{array}$ & $\begin{array}{l}29.7 \\
\pm 5.4\end{array}$ & $\begin{array}{l}27.6 \\
\pm 4.6\end{array}$ & $\begin{array}{l}25.8 \\
\pm 3.9\end{array}$ & $\begin{array}{l}26.5 \\
\pm 4.2\end{array}$ & $\mathrm{~F}=1.707$ & 0.200 & $\mathrm{~T}=1.597$ & 0.122 \\
\hline
\end{tabular}

Table (4) Comparison of hyperpigmentation subtypes according to p53 genotypes in all studied patients.

\begin{tabular}{|c|c|c|c|c|c|c|c|c|c|c|}
\hline & & & $\begin{array}{l}\text { Arg/Arg } \\
\mathrm{N}=6\end{array}$ & $\begin{array}{l}\text { Arg/Pro } \\
\mathrm{N}=9\end{array}$ & $\begin{array}{l}\text { Pro/Pro } \\
\text { N=15 }\end{array}$ & $\begin{array}{l}\text { Arg/Pro+ } \\
\text { Pro/Pro } \\
\text { N=24 }\end{array}$ & Test1 & $\mathbf{P}^{1}$ & Test2 & $\mathbf{P}^{2}$ \\
\hline \multirow[t]{3}{*}{ Subtypes } & Pigmented & $\mathbf{N}$ & 4 & $\begin{array}{l}5 \\
556 \%\end{array}$ & $\begin{array}{l}7 \\
467 \%\end{array}$ & $\begin{array}{l}12 \\
50 \%\end{array}$ & $\mathrm{X} 2=0.714$ & 0.807 & $\mathrm{X} 2=0.53$ & 0.657 \\
\hline & Vascular & $\begin{array}{l}\mathrm{N} \\
\%\end{array}$ & $\begin{array}{l}2 \\
33.3 \%\end{array}$ & $\begin{array}{l}0 \\
0 \%\end{array}$ & $\begin{array}{l}4 \\
26.7 \%\end{array}$ & $\begin{array}{l}4 \\
16.7 \%\end{array}$ & $X 2=3.333$ & 0.235 & $\begin{array}{l}X 2=0.83 \\
3\end{array}$ & 0.571 \\
\hline & Mixed & $\begin{array}{l}\mathrm{N} \\
\%\end{array}$ & $\begin{array}{l}0 \\
0 \%\end{array}$ & $\begin{array}{l}4 \\
44.4 \%\end{array}$ & $\begin{array}{l}4 \\
26.7 \%\end{array}$ & $\begin{array}{l}8 \\
33.3 \%\end{array}$ & $X 2=3.636$ & 0.134 & $\begin{array}{l}X 2=2.72 \\
7\end{array}$ & 0.155 \\
\hline
\end{tabular}

Table (5) Comparison of hyperpigmentation patterns according to p53 genotypes in all studied patients.

\begin{tabular}{lllllllllll}
\hline & & & $\begin{array}{l}\text { Arg/Ar } \\
\mathbf{g}\end{array}$ & $\begin{array}{l}\text { Arg/Pr } \\
\mathbf{0}\end{array}$ & $\begin{array}{l}\text { Pro/Pr } \\
\mathbf{0}\end{array}$ & $\begin{array}{l}\text { Arg/Pro+Pro/P } \\
\text { ro }\end{array}$ & Test1 & $\mathbf{P}^{1}$ & Test2 $^{\mathbf{P}^{2}}$ \\
& & & $\mathbf{N = 6}$ & $\mathbf{N = 9}$ & $\mathbf{N = 1 5}$ & $\mathbf{N = 2 4}$ & & & \\
\hline Patter & Homogenous & $\mathbf{N}$ & 3 & 7 & 12 & 19 & X2=2.91 & 0.42 & X2=2. & 0.300 \\
$\mathbf{n}$ & & $\mathbf{\%}$ & $50 \%$ & $77.8 \%$ & $80 \%$ & $79.2 \%$ & 7 & 2 & 088 & \\
& Heterogeneo & $\mathbf{N}$ & 3 & 2 & 3 & 5 & & & \\
& us & $\mathbf{\%}$ & $50 \%$ & $22.2 \%$ & $20 \%$ & $20.8 \%$ & & & \\
\hline
\end{tabular}


$\mathrm{P} 1$, comparison between $\mathrm{TT}, \mathrm{TC}, \mathrm{CC} ; \mathrm{p} 2$, comparison between TT, TC+CC. Numerical data are expressed as mean and SD, compared by t test for two groups, ANOVA for more than two groups; categorical data are expressed as number and percentage; compared by Chi square or Fisher exact tests.

VEGF (TC) genotype of pigmented variant has highest percentage \% in compared to other genotype in patient group with significant difference $(\mathrm{p}=0.014)$. figure (1)

No significant differences were found regarding hyperpigmentation patterns according to VEGFA genotypes in all studied patients $(\mathrm{p}>0.05)$. table 7

$\mathrm{P} 1$, comparison between TT, TC, CC; p2, comparison between $\mathrm{TT}, \mathrm{TC}+\mathrm{CC}$. Categorical data are expressed as number and percentage; compared by Chi square or Fisher exact tests.

Regression analysis was conducted for prediction of orbital hyperpigmentation susceptibility, using age, gender, FH, BMI, P35, VEGFA genotypes as covariates. Positive family history, P53 Arg/Pro+Pro/Pro and VEGFA TC+CC genotypes were associated with risk of orbital hyperpigmentation susceptibility in Univariable analysis. However, conducting a multivariable analysis on significant confounders in Univariable analysis revealed that only P53 and VEGFA genotypes were suggested to be risk predictors for orbital hyperpigmentation susceptibility. table (8)

Table (6) Comparison of demographic, family history and BMI according to VEGFA genotypes in all studied patients.

\begin{tabular}{|c|c|c|c|c|c|c|c|c|c|}
\hline & & $\begin{array}{l}\text { TT } \\
N=4\end{array}$ & $\begin{array}{l}\text { TC } \\
\mathrm{N}=17\end{array}$ & $\begin{array}{l}\mathrm{CC} \\
\mathrm{N}=9\end{array}$ & $\begin{array}{l}\mathrm{TC}+\mathrm{CC} \\
\mathrm{N}=26\end{array}$ & Test1 & $\mathbf{P}^{1}$ & Test2 & $\mathbf{P}^{2}$ \\
\hline $\begin{array}{l}\text { Age } \\
\text { (years) }\end{array}$ & $\begin{array}{l}\text { mean } \\
\pm \mathrm{SD}\end{array}$ & $\begin{array}{l}30.8 \\
\pm 9.1\end{array}$ & $\begin{array}{l}34.8 \\
\pm 10.9\end{array}$ & $\begin{array}{l}31.9 \\
\pm 10.3\end{array}$ & $\begin{array}{l}33.8 \\
\pm 11.2\end{array}$ & $\mathrm{~F}=0.319$ & 0.730 & $\mathrm{~T}=0.506$ & 0.616 \\
\hline Male & $\begin{array}{l}\mathrm{N} \\
\%\end{array}$ & $\begin{array}{l}1 \\
25 \%\end{array}$ & $\begin{array}{l}1 \\
5.9 \%\end{array}$ & $\begin{array}{l}1 \\
11.1 \%\end{array}$ & $\begin{array}{l}2 \\
7.7 \%\end{array}$ & $X 2=1.333$ & 0.525 & $X 2=1.154$ & 0.360 \\
\hline Female & $\begin{array}{l}\mathbf{N} \\
\%\end{array}$ & $\begin{array}{l}3 \\
75 \%\end{array}$ & $\begin{array}{l}16 \\
94.1 \%\end{array}$ & $\begin{array}{l}8 \\
88.9 \%\end{array}$ & $\begin{array}{l}24 \\
92.3 \%\end{array}$ & & & & \\
\hline $\begin{array}{l}\text { Positive } \\
\text { family } \\
\text { history }\end{array}$ & $\begin{array}{l}\mathrm{N} \\
\%\end{array}$ & $\begin{array}{l}3 \\
75 \%\end{array}$ & $\begin{array}{l}11 \\
64.7 \%\end{array}$ & $\begin{array}{l}3 \\
33.3 \%\end{array}$ & $\begin{array}{l}14 \\
53.8 \%\end{array}$ & $X 2=2.990$ & 0.295 & $X 2=0.632$ & 0.613 \\
\hline $\begin{array}{l}\text { BMI } \\
(\mathrm{Kg} / \mathrm{m} 2)\end{array}$ & $\begin{array}{l}\text { mean } \\
\pm \mathrm{SD}\end{array}$ & $\begin{array}{l}26.8 \\
\pm 5.2\end{array}$ & $\begin{array}{l}27.6 \\
\pm 5.2\end{array}$ & $\begin{array}{l}26.3 \\
\pm 3.1\end{array}$ & $\begin{array}{l}27.2 \\
\pm 4.5\end{array}$ & $F=0.227$ & 0.798 & $\mathrm{~T}=0.163$ & 0.872 \\
\hline
\end{tabular}

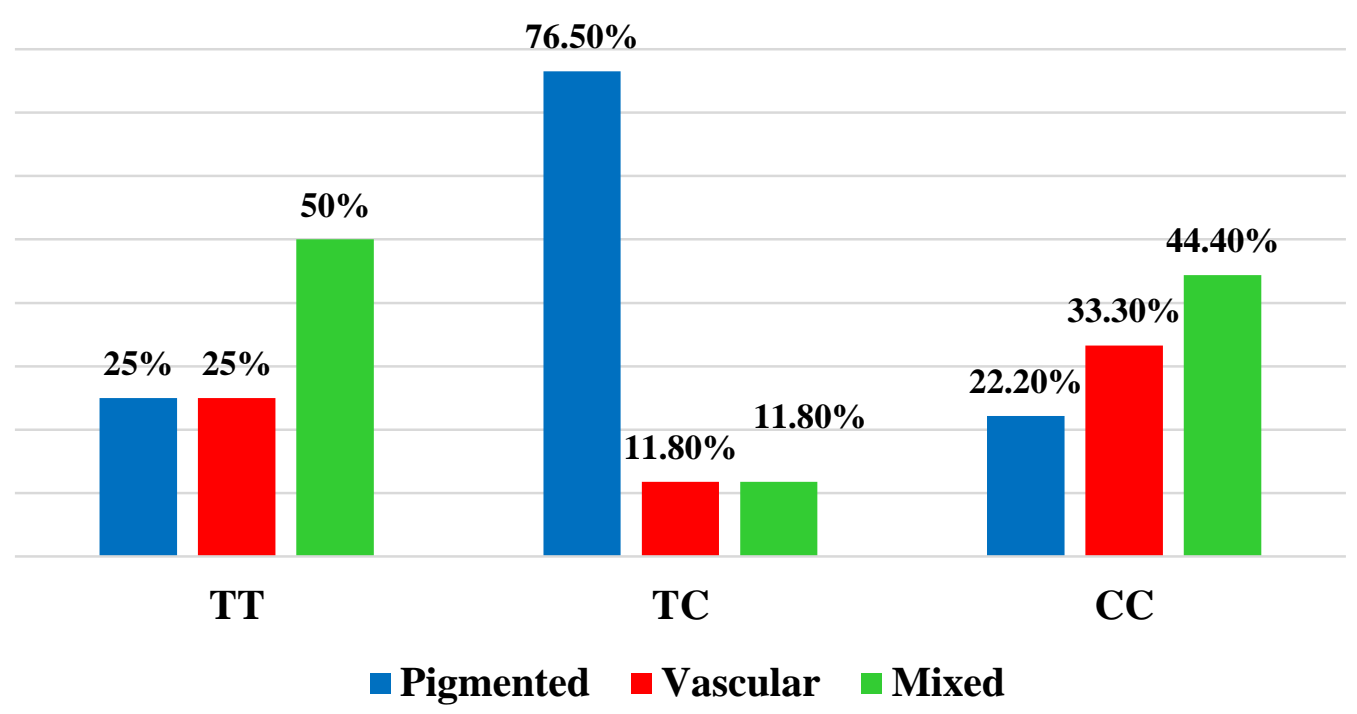

Fig. (1) Hyperpigmentation subtypes according to VEGFA genotypes in all studied patients. 
Table (7) Comparison of hyperpigmentation patterns according to VEGFA genotypes in Periorbital hyperpigmentation patient.

\begin{tabular}{lllllllllll}
\hline & & & $\mathbf{T T}$ & $\mathbf{T C}$ & $\mathbf{C C}$ & $\mathbf{T C}+\mathbf{C C}$ & Test1 & $\mathbf{P}^{\mathbf{1}}$ & Test2 & $\mathbf{P}^{2}$ \\
& & & $\mathbf{N = 4}$ & $\mathbf{N = 1 7}$ & $\mathbf{N = 9}$ & $\mathbf{N = 2 6}$ & & & & \\
\hline Pattern & Homogenous & $\mathbf{N}$ & 3 & 13 & 6 & 19 & $\mathrm{X} 2=$ & 0.846 & $\mathrm{X} 2=$ & 0.935 \\
& & $\mathbf{\%}$ & $75 \%$ & $76.5 \%$ & $66.7 \%$ & $73.1 \%$ & 0.296 & & 0.007 & \\
& \multirow{2}{*}{ Heterogeneous } & $\mathbf{N}$ & 1 & 4 & 3 & 7 & & & \\
& & $\mathbf{\%}$ & $25 \%$ & $23.5 \%$ & $33.3 \%$ & $26.9 \%$ & & & & \\
\hline
\end{tabular}

Table (8) Regression analysis for prediction of orbital hyperpigmentation susceptibility.

\begin{tabular}{lcccccccc}
\hline & \multicolumn{4}{c}{ Univariable } & \multicolumn{5}{c}{ Multivariable } \\
& $\mathbf{p}$ & OR & \multicolumn{9}{c}{$\mathbf{9 5 \%}$ CI } & $\mathbf{p}$ & OR & 95\% CI \\
\hline Age & 0.933 & 0.998 & 0.963 & 1.035 & & & & \\
Gender & 0.325 & 1.659 & 0.605 & 4.551 & & & & \\
FH & 0.027 & 2.311 & 1.098 & 4.861 & 0.078 & 2.158 & 0.918 & 5.074 \\
BMI & 0.612 & 0.980 & 0.904 & 1.061 & & & & \\
P53 Arg/Pro+Pro/Pro & 0.012 & 2.670 & 1.244 & 5.729 & 0.039 & 2.220 & 1.939 & 5.252 \\
VEGFA TC+CC & 0.006 & 3.175 & 1.396 & 7.221 & 0.007 & 3.541 & 1.419 & 8.833 \\
\hline
\end{tabular}

OR, odds ratio; $\mathrm{CI}$, confidence interval.

\section{Discussion}

There was no significant difference between the two groups in terms of age, gender, or body mass index. In the literature, contradictory findings have been published about the connection between gender and obesity. According to Besra et al.[7] and Nayak et al[8], $\mathrm{POH}$ is associated with women, whereas Zawar et al[9] found that $\mathrm{POH}$ is associated with obesity in women. The limited number of patients included in this research, as well as the fact that the control group was chosen to be age and gender matched, may explain our findings.

When compared to the control group, our research found that family history was substantially linked with $\mathrm{POH}(56.7 \%)$. (1). Univariate analysis showed a significant relationship between $\mathrm{POH}$ and a positive family history $(p=0.027)$, while multivariate analysis revealed no such association ( $p=0.008)$. Family history is associated with $\mathrm{POH}$ in Sheth et al. [10], Nayak et al. [8] and Mendiratta et al. [11]. This is likely due to the larger number of patients included in the study and also the fact that the study included a larger number of patients with chronic illness in addition to $\mathrm{POH}$.

$\mathrm{POH}$ and family history are associated with rs1437756379, a p53 gene whose pro allele has a prevalence of 65 percent in the case group and whose genotype has a prevalence of 50 percent (increase the risk of $\mathrm{POH}$ in the same family member) The control group has a greater frequency of the pro allele (Arg) (67.5 percent ) The p53 genotype did not seem to have a significant impact on hyperpigmentation subtypes in any of the patients examined. In the case group, rs833061 (VEGFA) has a greater frequency of the pro allele (C) and the genotype (Tc). A comparison of pigmented subtypes revealed that (Tc) genotypes accounted for the greatest proportion $(76.5 \%)$, as indicated in Chart 6.
In univariable analysis, a positive family history, the P53 Arg/Pro+Pro/Pro genotype, and the VEGFA $\mathrm{Tc}+\mathrm{Cc}$ genotype were linked with an increased risk of orbital hyperpigmentation susceptibility

Multivariate examination of relevant confounders in univariate analysis, however, showed that only the P53 and VEGFA genotypes seemed to be risk factors for orbital hyperpigmentation susceptibility

POH subtypes were identified and VEGFA and P53 single nucleotide polymorphisms (SNPs) were detected, according to Amini et al. [1]. Mixed (pigmented-vascular) was the most frequent subtype of POH. We identified 13 SNPs, however only three exhibited a meaningful relationship with periorbital hyperpigmentation. TA genotype in rs1437756379 (p53) was significantly more prevalent in participants with mixed subtype, and having a family member with $\mathrm{POH}$ was more prevalent in subjects with TA than TT.

According to this research, the existence of various variants of periorbital hyperpigmentation and the subsequent failure of conventional therapy in certain individuals may be explained by gene variation.

\section{Conclusion}

According to our findings, periorbital hyperpigmentation is associated with the p53 Pro/Pro and Arg/Pro+Pro/Pro/Pro genotypes, as well as the Pro allele, VEGFA TC, TC $+\mathrm{CC}$, and $\mathrm{C}$ allele. There was a strong association between the VEGFA TC genotype and the pigment subtype. Otherwise. There was no relationship between VEGFA rs833061 and any of the VEGFA variants (p53 rs1042522 or p53 rs1042522). For orbital hyperpigmentation susceptibility, P53 and VEGFA genotypes have been proposed as risk factors. 


\section{References}

[1] F.Amini, N. M. Thazin Oo, P. N. Okechukwu, M. S. Seghayat, and E. S. C. $\mathrm{Ng}$, "Polymorphisms in P53 and VEGFA genes in different subtypes of periorbital hyperpigmentation in a Malaysian Chinese population," Australas. J. Dermatol.vol.60,pp.99-104,2019.

[2] H. Ranu, S. Thng, B. K. Goh, A. Burger, and C. L. Goh, "Periorbital hyperpigmentation in Asians: an epidemiologic study and a proposed classification," Dermatologic Surg.vol.37,pp. 1297-1303,2011.

[3] R. Sarkar, R. Ranjan, S. Garg, V. K. Garg, S. Sonthalia, and S. Bansal, "Periorbital hyperpigmentation: a comprehensive review," J. Clin. Aesthet. Dermatol.vol.1,pp.49-55,2016.

[4] A. Hedayatizadeh-Omran et al., "Association of P53 gene polymorphism with gastric cancer in Northern Iran as a high-risk region," Biomed. reports.vol.8,pp.433-438,2018.

[5] D. Murase, A. Hachiya, Y. Amano, A. Ohuchi, T. Kitahara, and Y. Takema, "The essential role of p53 in hyperpigmentation of the skin via regulation of paracrine melanogenic cytokine receptor signaling," J. Biol. Chem.vol.284,pp.4343-4353,2009.

[6] X. Wu et al., "Polymorphisms in the VEGFA promoter are associated with susceptibility to hepatocellular carcinoma by altering promoter activity," Int. J. Cancer.vol.133,pp.1085-1093, 2013.

[7] L. Besra, T. J. Jaisankar, D. M. Thappa, M. Malathi, and R. Kumari, "Spectrum of periorbital dermatoses in South Indian population," Indian J Dermatol Venereol Leprol.vol.79,pp.399-407,2013.

[8] C. S. Nayak, A. S. Giri, and U. S. Zambare, "A study of clinicopathological correlation of periorbital hyperpigmentation," Indian Dermatol. Online J.vol.9,pp.245-488,2018.

[9] V. Zawar, S. Daga, M. Pawar, and S. Kumavat, "Periorbital pigmentation: An alarming sign of metabolic syndrome," J. Cosmet. Dermatol.vol.18,pp.1584-1586,2019.

[10] P. B. Sheth, H. A. Shah, and J. N. Dave, "Periorbital hyperpigmentation: A study of its prevalence, common causative factors and its association with personal habits and other disorders," Indian J. Dermatol.vol.59,pp.151$166,2014$.

[11] V. Mendiratta, S. Rana, R. Jassi, and R. Chander, "Study of causative factors and clinical patterns of periorbital pigmentation," Indian Dermatol. Online J.vol.10,pp.293,2019. 